\title{
Morphometric characterization of Katjang goat of Malaysia
}

\author{
Khandoker MAMY ${ }^{1 *}$, M Syafiee ${ }^{1}$ and MSR Rahman ${ }^{182}$
}

${ }^{1}$ Faculty of Sustainable Agriculture, Universiti Malaysia Sabah, 90509 Sandakan, Sabah, Malaysia; ${ }^{2}$ Department of Poultry Science, Bangladesh Agricultural University, Mymensingh 2202, Bangladesh

\begin{abstract}
Morphometric characterization of Katjang goat in Malaysia is important for conservation and for further genetic improvement. With this idea in view the present study was carried out to characterize the morphometry and to estimate the relationship among the important morphometric traits of indigenous Katjang goat. The study was conducted at the Faculty of Sustainable Agriculture (FSA), surrounding area of FSA Sandakan, Sabah and Batu Pahat, Johor in Malaysia. Characteristics of body weight (BW), body length $(B L)$, heart girth $(H G)$, wither height $(W H)$, hip height $(H H)$, fore leg length (FLL), hind leg length (HLL), head length (HeL), head width $(\mathrm{HW})$, ear length(EL), ear breadth $(\mathrm{EB})$, tail length $(\mathrm{TL})$, scrotal length (SL) and scrotal circumference (SC) were gathered. In a single parameter as body weight of Katjang bucks at below 1 year, 1-2 year and > 2 years ages were recorded to be 7.41 \pm 0.27 , $14.20 \pm 0.20$ and $25.83 \pm 0.99 \mathrm{~kg}$, respectively. On the hand, body weight of Katjang does at 1-2 year and $>2$ years ages were observed to be $12.41 \pm 0.41$ and $23.65 \pm 0.87 \mathrm{~kg}$, respectively. In both sexes, head length, head width, tail length, ear length, ear breath, body weight, body length, hearth girth, wither height, leg length, hip height increases with the increment of the age of goat. On the other hand, all the parameters contemplated found comparatively higher in bucks than that of does. Strong positive correlation was observed between scrotal length and scrotal circumference in Katjang bucks.
\end{abstract}

Key words: body parameters, head and tail parameters, reproductive parameters, Katjang goat

Bangladesh Animal Husbandry Association. All rights reserved.

Bang. J. Anim. Sci. 2016. 45 (3):17-24

\section{Introduction}

Over thousands of years, goats have provided mankind with useful products like meat, milk and skin (Ensminger and Parker, 1986). According to FAOSTAT (2008), the world goat population size is 861.9 million with the highest number in Asia (514.4 million), followed by Africa (291.1 million), South America (21.4 million), Europe (18.0 million), Central America (9.0 million), Northern America (3.0 million) and Oceania (0.9 million). Goats disseminated all over the world because their adaptability to varying environmental conditions and the different nutritional regimes under which they were evolved and subsequently maintained (Mia, 2012). However, it is easier to adapt in the region of arid, tropical and temperate. In the developing countries, goats make a very valuable contribution, especially to the poor in the rural areas (Mia, 2012). Malaysia has only one indigenous goat of its own, known as Katjang goat.
Katjang goat is a meat-type animal and it is found in small populations in several parts of Malaysia. Now a day, due to unplanned cross breeding with Boer and Jamnapari it is considered to be at risk (DVS, 2006). It possesses the morphological characteristics of a thin, blackcolored coat, sometimes with white patches and sometimes also found with black and brown coat coloration (DAD-IS, 2010). As an indigenous goat, Katjang possesses the natural characteristics of heat and tick tolerance under the tropical climate. Although their meat production may be relatively low compared to exotic goat breeds in Malaysia but their prolificacy is high and highly adapted to the local equatorial environment (FAO, 1992).

Limited information so far been available of Katjang goat (DVS, 2014 and Erinie et al., 2010) and morphometric characterization marks the first step for classification of Animal Genetic Resource (Delgado et al., 2001). In general, the observed morphometric characteristics of goat genetic resources with the characterization at molecular level will contribute to designing of

\section{*Corresponding author: mamyahiak@ums.edu.my}


improvement strategies for these goat populations, which will need to be complemented with the performance data. The importance of this valuable genetic resource in Malaysia is underestimated and its extent of contribution to the livelihood of the poor is inadequately understood. Research and development investments to improve the relatively low level of goat's productivity do not match their potential importance, resulting in many goat breeds that are not genetically explored, especially in the developing countries. Nevertheless, goats are going to be more important source of livelihood for more people in future and thus they deserve greater attention at both the micro and macro levels.

Though some sort of works so far been done on Katjang goat (DVS, 2014 and Erinie et al., 2010) still need to do a lot of works. During selection of goat attention should be given on the age, growth rate, body weight, heart girth, body length, height at wither and soundness of the sexual organ (Paul et al., 2011). Body length and heart girth may be used as good reliable predictors to assess live weight (Bhattacharya et al., 1984). Islam et al., (1991) reported that heart girth in males is good predictors of live weight in Bengal goats. On the other hand, positive correlation was reported among the traits of body weight, body length, height and heart girth in Black Bengal goat (Paul et al., 2011). Scrotal circumference has great value as indicator of genetic trait, puberty and total spermatozoa production in bulls (Ott, 1986). Determination of scrotal length and circumference is an important aspect of breeding soundness in Black Bengal goat (Paul et al., 2011).

The morphometry is a result of both genotype and the environment and these characteristics include as presence or absence of horns, coat color, body length, wither height, heart girth, tail length, tail type etc (Parvez et al., 2009). With this idea in view present study was undertaken to characterize the Katjang goat in Malaysia.

\section{Materials and Methods}

This study was carried out initially in the goat farm of the Faculty of Sustainable Agriculture (FSA, Universiti Malaysia Sabah (UMS) Sandakan campus and in some rural community areas around FSA campus. As the number of goats obtained was less then this study was further conducted to some farms in Batu Pahat which is situated in Johor, Malaysia. A total of 51 Katjang goats of different age and both sexes were randomly selected for this study from 8 farms. The feeding and management practice were as usual and in general, the farmers were provide Napier grass twice a day as per requirement. Most of the farms, also provided the palm kernel cake (PKC) and or palm kernel mash (PKM) 500 $\mathrm{g} / \mathrm{d} / \mathrm{goat}$.

\section{Data collection}

The data were collected in semi-structured data collection sheets along with visual appraisal of the appearance of the goat and measurements following the description lists of Food and Agriculture Organization (FAO, 1986) of the United Nations. Focus group discussion was also done either with the manager of the farm or concern key persons for generating general information regarding the history of the goat collection, special distinguished features of the targeted goats, production systems, and knowledge on the husbandry practices, challenges and opportunities of Katjang goat. Furthermore, data obtained from this study were based on the field survey taking rural community goat raisers' opinion, direct measurement and weighing of animals. Besides, as farmers did not have birth record of their animals, age of each goat was estimated by dentition as suggested by Pace and Wakeman (2003).

\section{Parameters measurement}

Goats of both sexes in different ages were used for morphometric characterization. The color of each sampled goat was observed very carefully and recorded. The body weight of the individual goat was taken in kilogram $(\mathrm{kg})$ by weighing scale from all age classes and data was recorded in the morning before feeding the animal. Furthermore, data collection were - extended on body length, heart girth, wither height, hip height, fore length, hind length, head length, head width, ear length, ear breadth, tail length, scrotal length and scrotal length. All measurements were taken by measuring tape in $\mathrm{cm}$. 


\section{Head and tail parameter measurement}

Head and tail parameters were measured as; (a) the distance of the length of the head was measured centrally from in-between the base of the horns to the tip of the mouth. (b) The distance of head width was measured in between tips of the right eye to the left eye. (c) The distance of ear length was measured from the base to the tip of the ear. (d) The distance of ear width was measured in-between the inside of the ear. (e) The distance of tail length was measured from the base to the tip of the tail.

\section{Body parameters measurement}

The body parameter measurement of Katjang goat was done by using electronic weighing scale and measuring tape as; (a) the body weight was taken by using an electronic weighing balance,(b) body length was measured as the distance between point shoulder to the pin bone, (c) the heart girth circumference was measured immediately posterior to the front leg, (d) the distance of wither height was measured from the top of the shoulder to the sole of the hoof, (e) the hind leg length was measured from pelvic girdle to the sole of the hoof, $(f)$ the fore leg length was measured from shoulder blade to the sole of the hoof and ( $\mathrm{g}$ ) the distance of hip height was measured in between hip to the sole of the hoof.

\section{Reproductive parameter measurement}

The reproductive parameters of scrotal length and scrotal circumference of breeding bucks was taken by using measuring tape. Where; (a) the scrotal length was measured from the base to the tip of apex of the scrotum and (b) the scrotal circumference was measured on the circumference of the base, middle and apex of the scrotal and the average value was taken.

\section{Relationship of important morphometric parameters}

The correlation among the important morphometric parameters was also performed by using SPSS version 21.0. The important morphometric parameters considered from both sexes were body weight, body length, heart girth, wither height. On the other hand, correlation was also performed between scrotal length and scrotal circumference in case of breeding bucks.

\section{Data analysis}

The data collected was compiled, tabulated and analyzed in accordance with the objectives and descriptive statistics was performed with the help of IBM Statistical Package for Social Science (SPSS) for Windows Package Version 21.0.

\section{Results}

\section{Number of Katjang goat}

The morphometric data of Katjang goat was collected from total of 8 farms including FSA farm. The numbers of goat were varied from farm to farm. The highest number of Katjang goats were found in FSA farm (14), followed by Senggarang and Osman farm (7), Bai Khan farm (6), Musleh and Subhi farm (5), Sri Bertuah farm (4) and Sukimin farm (3).

\section{Katjang goat color}

The color of Katjang goat was recorded in either of black, brown, brown-black, black with white patches and brown with white patches as shown in represented Figure 1.

Table 1: Morphometric characterization of Katjang goats at various ages (head and tail parameters)

\begin{tabular}{|c|c|c|c|c|c|c|c|}
\hline Gender & $\begin{array}{c}\text { Age } \\
\text { (years) }\end{array}$ & $\begin{array}{c}\text { Numbers } \\
\text { (n) }\end{array}$ & $\begin{array}{c}\text { Head } \\
\text { length } \\
(\mathrm{cm}) \\
\text { Mean } \pm \text { SE }\end{array}$ & $\begin{array}{c}\text { Head } \\
\text { width }(\mathrm{cm}) \\
\text { Mean } \pm \text { SE }\end{array}$ & $\begin{array}{c}\text { Tail length } \\
(\mathrm{cm}) \\
\text { Mean } \pm \text { SE }\end{array}$ & $\begin{array}{l}\text { Ear length } \\
(\mathrm{cm}) \\
\text { Mean } \pm \mathrm{SE}\end{array}$ & $\begin{array}{c}\text { Ear } \\
\text { breadth } \\
(\mathrm{cm}) \\
\text { Mean } \pm \mathrm{SE}\end{array}$ \\
\hline \multirow[t]{3}{*}{ Bucks } & $<1$ & 4 & $12.83 \pm 0.35$ & $8.51 \pm 0.28$ & $7.87 \pm 0.15$ & $10.86 \pm 0.15$ & $5.21 \pm 0.13$ \\
\hline & $1-2$ & 9 & $15.13 \pm 0.56$ & $11.65 \pm 0.24$ & $9.87 \pm 0.20$ & $12.24 \pm 0.37$ & $5.70 \pm 0.20$ \\
\hline & $>2$ & 11 & $15.66 \pm 1.13$ & $12.57 \pm 0.24$ & $14.82 \pm 0.25$ & $13.21 \pm 0.37$ & $6.69 \pm 0.20$ \\
\hline \multirow[t]{2}{*}{ Does } & $1-2$ & 15 & $15.17 \pm 0.37$ & $10.55 \pm 0.28$ & $9.15 \pm 0.18$ & $11.93 \pm 0.29$ & $5.40 \pm 0.12$ \\
\hline & $>2$ & 12 & $14.58 \pm 1.06$ & $11.91 \pm 0.25$ & $14.57 \pm 0.21$ & $13.27 \pm 0.36$ & $6.73 \pm 0.18$ \\
\hline
\end{tabular}




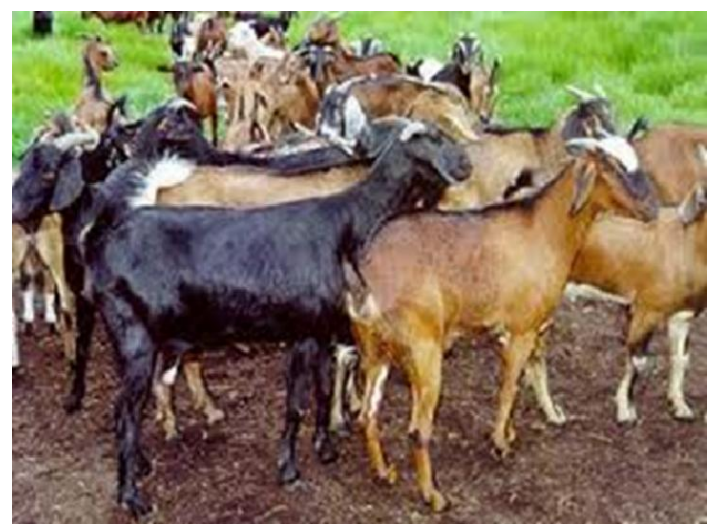

Figure1. Color variation of Katjang goats

\section{Head and tail parameter}

For morphometric characterization head and tail parameters are summarized in Table 1 . From this Table, it can be seen that the head lengths and widths were differed in different age groups. Moreover, it was observed that bucks always possessed higher head length and width than that of does. The head lengths and widths in bucks at below 1 year age, 1 to 2 years and more than 2 years ages were observed as $12.83,15.13,15.66$ and $8.51,11.65,12.57$, respectively in present study. It was also found that the head length and width in does at below 1 to 2 years and more than 2 years ages were 15.17, 14.58 and 10.55, 11.91, respectively. Tail length of bucks and does were also summarized in same Table 1 . The tail lengths were differed significantly $(p<0.01)$ by age groups. It also observed that tail length in bucks are comparatively higher than that of does. In this study, the tail lengths of bucks at below 1 year age, 1 to 2 years and more than 2 years ages were $7.87,9.87$ and 14.82 , respectively. It was also found the tail lengths in does at below 1 to 2 years and more than 2 years ages were 9.15 and 14.57 , respectively.

From Table 1, it was observed that the ear length and breadth of bucks and does not differed severely in different age groups. Ear length and breadth of bucks at below 1 year, 1 to 2 years and more than 2 years ages were $(10.83,12.24$, $13.21)$ and $(5.21,5.70,6.69)$ respectively. It was also found that ear length and breadth of bucks at 1 to 2 years and more than 2 years ages were (11.93, 13.27) and (5.40, 6.73), respectively.

\section{Body parameters}

The body parameters of Katjang goat bucks and does are summarized in Table 2. In the present study, the average body weight of Katjang bucks at below 1 year of age was recorded $7.41 \mathrm{~kg}$. The average body weight of males at 1-2 years age found $2.55 \mathrm{~kg}$ higher than that of females. Further the body weight of males at more than 2 years age also found $2.18 \mathrm{~kg}$ higher than that of the females. The body weight of Katjang goats of both sexes were increased with the increment of ages (Table 2). Body length also differed in different age groups and body lengths of bucks were found higher than that of does. The body length in bucks at below 1 year, 1 to 2 years and above 2 years ages were 36.31, 46.52 and 73.60 , respectively. While in does at 1 to 2 years and above 2 years ages were 42.15 and 70.50, respectively. Similarly the heart girth of bucks was found higher than does at different age groups. Hearth girth values in bucks at below 1 year, 1 to 2 years and more than 2 years ages were 44.54, 55.73 and $67.73 \mathrm{~cm}$, respectively. While in does, at 1 to 2 years and more than 2 years ages were 53.47 and $63.46 \mathrm{~cm}$, respectively.

Again the wither height, hind and fore leg length were found higher in bucks than that of does at different age groups. In bucks, the wither height, hind and fore leg length at below 1 year, 1 to 2 years and more than 2 years ages were (36.55, $46.90,52.34),(39.17,47.94,47.90)$ and $(20.83$, $26.01,30.55) \mathrm{cm}$, respectively. But in does, the wither height, hind and for leg length at 1 to 2 years and more than 2 years ages were (43.10, 50.21), (46.51, 44.70) and $(20.14,39.48) \mathrm{cm}$, respectively. From Table 2, it was also observed that the fore and hind leg length of bucks was always recorded higher than that of does.

\section{Reproductive parameters}

The result of scrotal length and scrotal circumference of Katjang goat breeding bucks is summarized in Table 3 . The scrotal length and circumference in bucks were recorded higher at more than 2 years age than that of other age group. The scrotal length and circumference at 1 year, 1 to 2 years age and more than 2 years age are $(7.81,9.94,12.75)$ and $(4.73,14.60,15.46)$, respectively. 
Characterization of Katjang goat

Table 2: Morphometric characterization of Katjang goats at various ages (body parameters)

\begin{tabular}{lccccccccc}
\hline Gender & $\begin{array}{c}\text { Age } \\
(\mathrm{yrs})\end{array}$ & No. & $\begin{array}{c}\text { Body weight } \\
(\mathrm{kg}) \\
\text { Mean } \pm \mathrm{SE}\end{array}$ & $\begin{array}{c}\text { Body } \\
\text { length }(\mathrm{cm}) \\
\text { Mean } \pm \text { SE }\end{array}$ & $\begin{array}{c}\text { Heart } \\
\text { girth }(\mathrm{cm}) \\
\text { Mean } \pm \text { SE }\end{array}$ & $\begin{array}{c}\text { Wither } \\
\text { height }(\mathrm{cm}) \\
\text { Mean } \pm \text { SE }\end{array}$ & $\begin{array}{c}\text { Hind leg } \\
\text { length }(\mathrm{cm}) \\
\text { Mean } \pm \mathrm{SE}\end{array}$ & $\begin{array}{c}\text { Fore leg } \\
\text { length }(\mathrm{cm}) \\
\text { Mean } \pm \mathrm{SE}\end{array}$ & $\begin{array}{c}\text { Hip Height } \\
(\mathrm{cm}) \\
\text { Mean } \pm \mathrm{SE}\end{array}$ \\
\hline Bucks & $<1$ & 4 & $7.41 \pm 0.27$ & $36.31 \pm 0.65$ & $44.54 \pm 0.85$ & $36.55 \pm 0.72$ & $39.17 \pm 0.81$ & $20.83 \pm 0.34$ & $23.58 \pm 0.43$ \\
& $1-2$ & 9 & $14.20 \pm 0.20$ & $46.52 \pm 0.77$ & $55.73 \pm 0.33$ & $46.90 \pm 0.33$ & $47.94 \pm 0.33$ & $26.01 \pm 0.27$ & $28.60 \pm 0.19$ \\
& $>2$ & 11 & $25.83 \pm 0.99$ & $73.60 \pm 1.96$ & $67.73 \pm 2.41$ & $52.34 \pm 1.93$ & $49.70 \pm 0.33$ & $30.55 \pm 0.99$ & $34.80 \pm 1.16$ \\
\multirow{3}{*}{ Does } & $1-2$ & 15 & $12.41 \pm 0.41$ & $42.15 \pm 0.55$ & $53.47 \pm 0.83$ & $43.10 \pm 0.74$ & $46.51 \pm 0.93$ & $24.14 \pm 0.43$ & $26.63 \pm 0.54$ \\
& $>2$ & 12 & $23.65 \pm 0.87$ & $70.50 \pm 1.35$ & $63.46 \pm 2.31$ & $50.21 \pm 1.79$ & $44.70 \pm 0.37$ & $39.48 \pm 0.88$ & $32.60 \pm 1.13$ \\
\hline
\end{tabular}

Relationship of important morphometric parameters

The relationships of body weight with body length, heart girth, wither height, scrotal length, and scrotal circumferences for bucks are presented in Table 4. In bucks, the body weight had significant correlation $(\mathrm{p}<0.01)$ with body length (0.832), heart girth (0.896), wither height (0.878), scrotal length (0.793), and scrotal circumference $(0.815)$.It was observed that body length in bucks has significantly $(p<0.01)$ correlated with body weight $(0.832)$, heart girth (0.905), wither height (0.973), scrotal length $(0.858)$ and scrotal circumference (0.872) (Table 4).

Table 3: Reproductive parameters of Katjang goat breeding bucks at various ages

\begin{tabular}{cccc}
\hline $\begin{array}{c}\text { Age } \\
\text { (years) }\end{array}$ & $\begin{array}{c}\text { Observat } \\
\text { ion }\end{array}$ & $\begin{array}{c}\text { Scrotal } \\
\text { length }(\mathrm{cm}) \\
\text { Mean } \pm \text { SE }\end{array}$ & $\begin{array}{c}\text { Scrotal } \\
\text { circumferences }(\mathrm{cm}) \\
\text { Mean } \pm \text { SE }\end{array}$ \\
\hline$<1$ & 4 & $7.81 \pm 0.20$ & $4.73 \pm 0.32$ \\
$1-2$ & 9 & $9.94 \pm 0.37$ & $14.60 \pm 0.24$ \\
$>2$ & 11 & $12.75 \pm 0.31$ & $15.46 \pm 0.23$
\end{tabular}

On the other hand, the relationship of body length with body weight, heart girth and wither height for does is presented in Table 5. It was observed that body weight has highly significant correlation $(p<0.01)$ with body length $(0.851)$, heart girth (0.879) and wither height (0.885).Similarly body length has also highly significant correlation $(p<0.01)$ with hearth girth (0.841) and wither height (0.913). Highly significant correlation $(p<0.01)$ was further found between hearth girth and wither height (0.943) (Table 5). It was observed that heart girth in bucks has highly significant correlation $(p<0.01)$ with body weight $(0.896)$, body length (0.905), wither height (0.941), scrotal length (0.895) and scrotal circumference $(0.897)$ (Table 4$)$. On the other hand in does, the heart girth has highly significant correlation $(p<0.01)$ with body weight (0.879), body length (0.841) and wither height (0.943) (Table 5).

\section{Discussion}

\section{Number of Katjang goat}

The number of Katjang goat varies $3-14$ in different 8 farms and the least number ( 3 heads) were found in Sukimin goat farm and the highest numbers were recorded in FSA farm (14 heads). The results revealed that the number of Katjang goats were not large numbers in Malaysia. Comparatively moderate number of Katjang goat was found in FSA farm (14) as this farm recently established with accumulating the pure Katjang goats from different places for students demonstration. Though the production potentiality of Katjang goat relatively low compared to other goat breeds might results in declining economic interest of the farmers. However, it is necessary to conserve such breed since indigenous breeds have unique adaptive qualities (FAO, 1912).

\section{Color}

The color of Katjang goat varies from black, brown, brown-black, black with white patches or brown with white patches as shown Figure 1. DVS Malaysia (2006) has reported that Katjang goat's coat color varies from dark chocolate to black. The coat color of Katjang goat usually is Black, sometimes with white patches on the belly and feet (Devendra and Nozawa, 1966). Due to unplanned breeding the dilution of Katjang goat might be occurred in certain level and this might be the cause of color variation reported in this study and further investigation is required for more confirmation. 
Table 4: Relationship of body weight with body length, heart girth, wither height, scrotal length and scrotal circumference in Katjang goat bucks $(* * p<0.01)$

\begin{tabular}{lccccc}
\hline & $\mathbf{1}$ & $\mathbf{2}$ & $\mathbf{3}$ & $\mathbf{4}$ & $\mathbf{5}$ \\
\hline Body weight (1) & - & - & - & - & $\mathbf{6}$ \\
Body length (2) & $0.832^{* *}$ & - & - & - & - \\
Heart girth (3) & $0.896^{* *}$ & $0.905^{* *}$ & - & - & - \\
Wither height (4) & $0.878^{* *}$ & $0.973^{* *}$ & $0.941^{* *}$ & - & - \\
Scrotal length (5) & $0.793^{* *}$ & $0.858^{* *}$ & $0.895^{* *}$ & $0.836^{* *}$ & - \\
Scrotal circumferences (6) & $0.815^{* *}$ & $0.872^{* *}$ & $0.897^{* *}$ & $0.834^{* *}$ & $0.952^{* *}$ \\
\hline$*$ p p 0.01 & & & & &
\end{tabular}

\section{Head and tail parameter}

Morphometric parameters of Katjang goat are almost similar to Black Bengal goat. Rahmanet al. (2008) reported that the head length and width of Black Bengal bucks at 1 year age are 16.67 and 12.33 , respectively and these findings are similar to the present study. Hasanat et al. (2003) also reported that the head length of male and female at 1 year age were 15.53 and 15.49 which are slightly higher than the present result and might be due to breed variation.

It was observed that the ear length and breadth of bucks and does not varied and similar results was also found in Black Bengal goat (Rahmanet al.2008and Alam, 2006). Hasanat et al. (2003) reported the average ear length and breadth of Black Bengal bucks and does at 1 year age were $(12.87,5.54)$ and $(12.57,5.43) \mathrm{cm}$, respectively which are close agreement with the results of this study.

\section{Body parameter}

In all cases body weight of bucks are comparatively higher than that of does. Devendra and McLeroy (1982) reported the similar result and they reported the average mature weight of male and female goats were $25 \mathrm{~kg}$ and $20 \mathrm{~kg}$, respectively. Rahmanet al. (2008) strongly supported our present finding and he reported almost similar correlation between body weight and heart girth (0.937), body weight and body length (0.939) as well as body weight and height at wither (0.934). Hasanat et al. (2003) reported that sex had significant influence $(p<0.01)$ on body length. It's supported the present study of higher average body length of bucks than that of does at different age groups. The findings of the present study supports the results of Rahmanet al.(2008) who found positive correlation between body weight and body length (0.939), heart girth (0.98) and wither height (0.969) and Khan et al. (1992) who found correlation between body weight and body length (0.64). In the present study, it was found that age has a significant effect on heart girth.

Table 5: Relationship of body weight with body length, heart girth and wither height in Katjang goat does

\begin{tabular}{lcccc}
\hline & $\mathbf{1}$ & $\mathbf{2}$ & $\mathbf{3}$ & $\mathbf{4}$ \\
\hline Body weight (1) & - & - & - & \\
Body length (2) & $0.851^{* *}$ & - & - & \\
Heart girth (3) & $0.879^{* *}$ & $0.841^{* *}$ & - & \\
Wither height (4) & $0.885^{* *}$ & $0.913^{* *}$ & $0.943^{* *}$ & - \\
\hline$* * \mathrm{p}<0.01$ & & &
\end{tabular}

In this study, it was also found that heart girth of bucks was higher than does at different age groups. Hasanat (2003) reported the average heart girth of bucks and does were 55.42 and $52.93 \mathrm{~cm}$ respectively. This variation might be due to breed variation, nutrition, and other management procedure. The result of the present study was found to be lower than the findings of Rahman et al. (2008) who found positive correlation between body weight and heart girth (0.937). The findings of the present study also supports the result obtained by Tandon (1966) who reported significant association between heart girth and body weight in Beetal goats.

The higher wither height and hip height was attained by male than female at different age groups. The findings of the present study support the results of Rahman et al. (2008), Noran and Mukherjee (1997) and Sigh et al. (1981). They reported that increase in height at wither 
reflected significantly $(p<0.001)$ on the increase of body weight of the bucks. It was observed that the fore leg length and hip height of bucks was always higher than the does. In this study, the average leg length for bucks and does at 1 to 2 years were 26.01 and 24.04 which support the results of Hasanat et al. (2003) who reported the average hind leg lengths of male and female were 25.91 and $25.04 \mathrm{~cm}$ respectively.

\section{Reproductive parameter}

Scrotal circumference is one of the important parameter of breeding males. Higher scrotal circumference indicates higher number of seminiferous tubules present in the testes which positively reflects on higher volume of semen production. Shamsudin et al. (2000) reported that the mean scrotal circumference of Black Bengal buck at puberty ranged from 14.0 to 16.0 $\mathrm{cm}$ which strongly supports the results of the present study.

\section{Conclusion}

Result of this study shows that the number of Katjang goat varies from farm to farm and number of goats were small. The results also indicated that the color of Katjang goat varies from black, brown, brown-black, black with white patches and brown with white patches. In both sexes, head length, head width, tail length, ear length, ear breath, body weight, body length, hearth girth, wither height, leg length, hip height increases with the increment of the age of goat. Finally it is possible to conclude that most of the economic parameters in Katjang goat are correlated.

\section{Conflict of interest statement}

We declare that we have no conflict of interest.

\section{Acknowledgement}

This research is supported by a research grant from the Universiti Malaysia Sabah (UMS), Malaysia to Prof. Dr. M. a. M. Yahia Khandoker at the Faculty of Sustainable Agriculture, UMS, Malaysia.

\section{References}

Alam MK (2006). Characterization and performance evaluation of white goat in some selected area of Bangladesh. MS Thesis. Department of Animal Breeding and Genetics, Bangladesh Agricultural University.

Ballantyne P (2013). Characterizing goat genetic resources in Ethiopia. Research on livestock and fish Research Institute of Biodiversity Conservation. Ethiopia.

Bhattacharya B, TK Ghosh, R Duttagupta and DN Maitra (1984). Estimation of body weight in Black Bengal goats from body measurements. Ind Vet J. 61: 406-408.

DAD-IS (2010). The Food and Agricultural Information System. FAO. DAD-IS, 2010. Domestic Animal Diversity Information System, FAO, http://dad.fao.org/.

Devendra C and GB Mcleroy (1982). Goat and sheep production in the tropics. Longman Scientific \& Technical- Longman Group, UK Limited - First Edition.

Delgado JV, C Barba, ME Camacho, FTPS Sereno, A Martinez and JL Vega-Pla (2001). Livestock characterization in Spain. Agric Rural Dev. 29: 7-18.

Devendra C and K Nozawa (1966). Goats in South East Asia-their status and production. J Anim Breed Gen. 93: 101-120.
DVS (Directorate of Veterinary Services, Malaysia). (2006). First report on the state of the world's animal genetic resources: Animal genetic resources in Malaysia. Animal genetic resources in Malaysia. The development of farming technology, Malaysia.

Ensminger ME and RO Parker (1986). Sheep and goat science, Fifth Edition. Danville, Illinois: The Interstate Printers and Publishers Inc.

Ernie Muneerah, MA, SI Salleh, AK Raymond, I Zawawi, AR Hafiz, MI Kamarulrizal, AM Hafizal, MI Kamaruddin and MA Abu Hassan (2010). Development of Katjang goat conservation center. In proceeding of 2 nd national conference onAgrobiodiversity conservation and sustainable utilization 11 -13 May 2010, Tawau,Sabah, Malaysia.

FAO (1986). Animal genetic resource data banks-2. Descriptor lists for cattle, buffalo, pigs, sheep and goats. Animal production and health paper No. 59/2, Rome, Italy.

FAO (1992). Animal genetic resources: strategies for improved use and conservation. FAO animal production and health paper 66 . Rome, Italy.

FAOSTAT (2008). Food and Agriculture Organization of the United Nations Statistics 2008. http://faostat.fao.org/default.aspx. Access on 13th March 2015. Verified on 12th April 2015.
DVS Malaysia (2014). List of applied research: 
Hasanat MT, SS Husain, MR Amin and G Miah (2003). Characterization of Black Bengal goats for some qualitative and quantitative traits. Bang J Anim Sci. 32: 109-120.

Islam MR, M Saadullah, MAR Howlider and MA Huq (1991). Estimation of live weight and dressed carcass weight from the different body measurements of goats. Ind J Anim Sci. 61: 460-461.

Khan RI, MR Alam and MAR Howlider (1992). Relationship of body measurements with meat and skin yield characteristics in free range reared Bengal goats. J App Anim Res. 2: 105111.

Mia MM (2012). Genetic evaluation of performance of Black Bengal goat. Ph D thesis. Department of Animal Breeding and Genetics, Bangladesh Agricultural University, Mymensingh-2202, Bangladesh.

Noran AM and TK Mukherjee (1997). Physical traits versus the buck's reproductive abilities. Aust J Anim Sci. 10: 245-250.

Ott RS (1986). Breeding soundness examination of bulls. In: current therapy in Theriogenelogy. WB Sounders Company. Philadelphia, USA 2 125136.

Pace JE and D Wakeman (2003). Determining the age of cattle by their teeth. Institute of Food and Agricultural Sciences (IFAS). University of Florida.
Parvez S, M Ershaduzzaman, MAI Talukder, MN Hasan and MAMY Khandoker (2009). Phenotypic characteristics of indigenous sheep of Bangladesh. Bang J Anim Sci. 38: 1-6.

Paul S, MAMY Khandoker, MA Moinuddin and RC Paul (2011). Characterization of Black Bengal goat. J Bang Agril Univ. 9: 61-66.

Rahman AHMS, MAMY Khandoker, SS Husain, AS Apu, A Mondal and DR Notter (2008). Morphometric characterization and relationship of body weight with linear body measurements in Black Bengal buck. Bang J Anim Sci. 37: 816.

Shamsuddin M, Y Amiri and MMU Bhuiyan (2000). Characteristics of Buck semen with regard to ejaculate numbers, collection intervals, dilution and preservation periods. Reprod Domestic Anim. 35: 53-57.

Singh CSP, DK Mukherjee, B Prasad and HR Mishra (1981). Note on body measurements and weights of Black and Brown Bengal goats. Ind J Anim Sci. 51: 234-236.

SPSS (1998). Windows for version-21.0. Microsoft Corporation. Trends SPSS Inc Michigan Avenue, Chicago, IL. 19-182.

Tandon HS (1966). Relationship of body weight with measurements in Beetal goats. Ind J Dairy Sci. 19: 187-190. 